\title{
The Business History Foundation, Inc.
}

A new research organization in the field of business history has recently been established, the Business History Foundation, Inc. Chartered under the membership corporations law of the State of New York as a non-profit organization, the Foundation is designed to carry on and facilitate research in the history of business and to assist in the publication of the results of such research. It will be financed by gifts from individuals, institutions, and companies.

The Foundation is an outgrowth of the research in the history of business that has in the past two decades been carried on under the direction of Professor N. S. B. Gras at the Graduate School of Business Administration of Harvard University. From the beginning the work in business history at the Harvard Business School has been based on the conviction that the study of the business man and unit at work, from original business records, is the first essential in the development of business history and that the heart of that study is found in the administration of the unit. Since the history of business had not previously been approached in this way, it became necessary to begin at the bottom and build up a body of information through research in the lives of business men and the history of firms. Professor Gras believed that only in this way could the basis. for more general studies in the history of business be laid.

In the course of the years a considerable group of men and women have worked with Professor Gras. The published results are the twelve volumes of Harvard Studies in Business, History, Gras' Business and Capitalism, and Gras and Larson's Casebook in American Business History, together with numerous articles which have appeared in the Journal of Economic and Business History, the Bulletin of the Business Historical Society. and other publications.

A wide interest in business history has in the meantime developed throughout the country. The attitude of many business men has changed from one of distrust of the historian and neglect. 
of history to an interest in coöperating with the scholar in ma:ing known to business, to the student, and to the public generally the past history of their companies. A number of scholars outside the Harvard group have also turned to business histo $y$, and several leading universities have established cotrses of instruction in the subject. Learned and fopular publications, alilic, have for several years manifested an increasing interst in the history of the administration and operation of business. In effect, interest in business history is in the process of developing into a "movement," in both business and academic circles. The growing interest in business history has highlighted the over-all problem of providing through research the factual information which is needed to keep the subject on a high plane and to forestall the development of a superficial treatment of business history which could be fatal to the realization of the substantial promise now existing.

Unfortunately there are serious difficulties in the way of supplying that fund of information. To begin with, there is the problem of financing research and study in a field which is so new that it does not have access to the traditional sources of aid for scholarly research and publication. The alternative has of necessity been to turn to business itself for financial aid, but when that is done there arises the problem of maintaining the independence of the researcher. Further problems arise out of the fact that the business historian must to a large extent wo:k in the records of living firms; only high social-mindedness on the part of a company's executives and scholarly objectivity and responsibility on the part of the scholar can eventuate in studies that are fair both to the company and to the scholar.

There is, moreover, the very serious problem of carrying on the large special research that would be involved in writing the history of a great modern corporation or holding company. No one scholar could get far in the study of the history of, let us say, the United States Steel Corporation. Yet without studies of some great concerns, business history would fall far short of meeting the need for information about the background of our present business system. Such studies involve problems of research and the financing of research which neither an individual nor even a large university could adequately handle.

The Business History Foundation, or some such organization, is necessary because of three situations. First, there must be 
trained an experienced staff of researchers and writers in the field of business history who can turn from one project to another with the fullness of knowledge of methods and ideals. Second, some special organization is required to direct and be responsible for each large piece of work. And, third, one organization is required to stand between the scholar and the sponsor of research so as to assure independence in study and writing.

The trustees of the Foundation are as follows: Dr. Joseph $\mathrm{H}$. Appel, retired executive of the Wanamaker stores, author, and trustee of Franklin and Marshall College; Dean Ray Palmer Baker of Rensselaer Polytechnic Institute; Professor N. S. B. Gras and Associate Professor Henrietta M. Larson of the Graduate School of Business Administration, Harvard University; and Dr. Charles W. Moore, assistant vice-president of SKF Industries, Inc. Professor Gras is president of the Foundation and Dr. Larson, on leave from Harvard, will serve as executive vice-president. The offices of the corporation will be in New York.

The Foundation has already arranged to assist in various undertakings, but its first large project will be the preparation of a history of the Standard Oil Co. (N.J.). This project was decided upon only after more than a year's exploratory study of its feasibility and importance. The company has made a gift to the Foundation to facilitate its work.

This project is planned to take at least five years and to result in no less than four volumes. The work will be done by a group of scholars including Professor Ralph W. Hidy and Professor Muriel Hidy of Wheaton College, Mrs. Evelyn H. Knowlton, Mr. George W. Gibb, and Mr. John S. Ewing of the Graduate School of Business Administration of Harvard University, and Dr. Charles S. Popple, formerly also of that School. Dr. Larson will be in charge for three years and will also participate in the research and writing. Professor Gras will act in a consulting capacity until retirement at Harvard frees him for more active participation.

The Standard Oil Co. (N.J.) will make its records available to these scholars, and the authors will decide what the facts are and determine the manner of presentation. The research will be exhaustive, the presentation candid, and publication unrestricted. The object will be the discovery of past activities and present trends, old mistakes and new challenges, private action and public sanction, organization and control, with emphasis on policy and 
management over the many decades of the Company's existence. Always the facts will be presented against the background of the times.

In opening its records to scholars the Standard Oil Co. (N.J.) is placing its support behind a new development in the social sciences. Business has long furthered research in the natural sciences, particularly in engineering. Many deans of schools of business have recommended the same emphasis in the social sciences. The Standard Oil Co. (N.J.) is doing precisely this without lessening its support of the natural sciences. To be sure, it is not the development of the natural sciences which has brought danger to our civilization, but rather the fact that the social sciences have not developed adequately to cope with the problems resulting from changes based upon discoveries in the natural sciences. This deficiency is notably true of modern business, which historian and economist, alike, have almost wholly neglected.

The logical summary of the Foundation's purpose is to provide facts for the building up of the social sciences, in the broad meaning of that discipline. There will be no lecturing; no magazines will be published; and no impressionistic history will be written. On the whole, it may be expected that the books resulting from the work of the Foundation will provide raw material and carefully formulated generalization which will aid business men, historians, and other social scientists to broaden their base, deepen their perspective, and increase their sense of historical relativity.

It seems fitting that America, which has led in the scientific study of business techniques, should also lead in the study of business statesmanship and should recognize that in the pursuit of wise policies and broad dispositions it is necessary to have a sound, factual, and documentary background in the development of business. It may well be that the understanding which business man, student, and public,. alike, will gain from the study of the history of the administrator of business and of the place of business in the history of the western world may have a broad significance. The new Foundation is expected to aid in a development which may change the traditional attitude of disdain for and distrust of business to a desire the better to understand and administer our business system. Thus a cultural lag which cuts deep in modern society would in some measure be corrected.

Henrietta M. Larson, Harvard University. 